\title{
Evaluasi Kognitif Santri Tentang Gizi Seimbang Di Masa Pandemi Covid-19 Melalui Edukasi
}

\author{
Esti Nur Janah ${ }^{1 *}$, Siti Fatimah ${ }^{2}$, Slamet Wijaya Biantoro ${ }^{3}$, Iqomatul Azizah ${ }^{4}$ \\ ${ }_{1,2,3,4}$ Akademi Keperawatan Al Hikmah 2 Brebes, Indonesia \\ *email:estiNJ@gmail.com
}

\begin{abstract}
Balanced nutrition during the Covid-19 pandemic is very important for the lifestyle of students because by consuming balanced nutrition, students can maintain health so that the virus does not easily enter the body and thus can break the chain of spreading the corona virus. Education on nutrition issues during the COVID-19 pandemic aims to provide knowledge and vigilance to students so that they pay more attention to their health, especially endurance. This community service activity was held at the Zayyinul Huda Islamic Boarding School, Kalierang Village with a total of 75 students. The activity was in the form of educational presentation of material related to balanced nutrition during the Covid-19 pandemic as well as providing a Guidebook for Balanced Nutrition for Santri during the Covid19 Pandemic. The material presented explained the importance of implementing balanced nutrition and a healthy lifestyle to maintain body resistance during the pandemic. The results of the cognitive evaluation showed that there was an increase in students' knowledge of the understanding of balanced nutrition during the Covid-19 pandemic after education was carried out, namely an increase in the average score of 18.2 from an average pre-test score of 57.5 to a post-test of 75.7 .
\end{abstract}

Keywords: Covid-19; cognitive evaluation; balanced nutrition; education

\begin{abstract}
Abstrak
Gizi seimbang pada masa pandemi Covid-19 sangat penting bagi pola hidup santri karena dengan mengkonsumsi gizi seimbang maka santri dapat menjaga kesehatan sehingga virus tidak mudah masuk kedalam tubuh dan dengan itu dapat memutuskan rantai penyebaran virus corona. Edukasi masalah nutrisi selama pandemi COVID-19 ini bertujuan untuk memberikan pengetahuan dan kewaspadaan terhadap santri sehingga lebih memperhatikan kesehatannya terutama daya tahan tubuh. Kegiatan pengabdian masyarakat ini diadakan di Pondok Pesantren Zayyinul Huda Desa Kalierang dengan jumlah peserta sebanyak 75 santri. Kegiatan berupa edukasi pemaparan materi terkait Gizi seimbang di masa pandemi Covid-19 sekaligus memberikan Buku Panduan Gizi Seimbang Pada Santri di Masa Pandemi Covid-19. Materi yang disampaikan menjelaskan pentingnya menerapkan gizi seimbang dan gaya hidup sehat untuk menjaga daya tahan tubuh selama pandemi. Hasil evaluasi kognitif didapatkan ada peningkatan pengetahuan santri terhadap pemahaman gizi seimbang di masa pandemik Covid-19 setelah dilakukan edukasi yaitu peningkatan skor rata-rata 18,2 dari skor rata-rata pre test 57,5 menjadi post test sebesar 75,7 .
\end{abstract}

Kata kunci: Covid-19;evaluasi kognitif; gizi seimbang; edukasi

\section{Pendahuluan}

Coronavirus Disease 2019 (COVID-19) disebabkan oleh Severe acute respiratory syndrome coronavirus 2 (SARS-CoV-2) yang menular dari hewan ke manusia dan menyebar lebih lanjut dari manusia ke manusia. COVID-19 dapat menimbulkan sindrom pernapasan akut yang berat. Kebanyakan infeksi sembuh sendiri namun 


\section{Prosiding Seminar Nasional Kesehatan Lembaga Penelitian dan Pengabdian Masyarakat Universitas Muhammadiyah Pekajangan Pekalongan}

COVID-19 dapat menyebabkan penyakit yang lebih parah pada populasi lansia atau pasien dengan riwayat medis bermasalah [1].

Pandemi COVID-19 ini mempengaruhi berbagai aspek kehidupan baik di dunia maupun Indonesia sendiri. Bukan hanya masalah kesehatan namun juga berpengaruh besar terhadap pendidikan dan sosial-ekonomi [2]. Lebih jauh, akan terjadi masalah nutrisi, mulai dari keamanan pangan, ketahanan pangan (ketersediaan), kesulitan pemenuhan kebutuhan nutrisi, stres, aktivitas fisik yang kurang sehingga menyebabkan munculnya berbagai masalah nutrisi seperti malnutrisi termasuk gizi kurang maupun obesitas, penyakit metabolik, penurunan daya tahan tubuh /sistem imun [3], [4].

Coronavirus Disease 2019 (Covid-19) sangat berbahaya dapat menimbulkan kematian, menimpa setiap orang, termasuk remaja yang tingkat imunitas rendah. Remaja merupakan masa transisi dari masa kanak-kanak ke tahap awal dewasa, mencakup aspek biologi, kognitif, dan perubahan sosial, berlangsung antara usia 10-19 tahun [5].

Santri di Pondok Pesantren Zayyinul Huda Jatisawit Kecamatan Bumiayu sebagian besar masuk dalam kategori usia remaja. Masalah kesehatan yang sering terjadi pada santri salah satu diantaranya adalah masalah gizi. kasus yang banyak dijumpai di lingkungan pondok peantren terkait gizi diantaranya adalah gangguan pencernaan (gastritis, diare), obesitas, dan kurang gizi. Masalah gizi yang sering didapat antara lain masakan yang kurang masak, masak beras yang tidak bersih, mie sebagai makanan pokok, mengambil porsi yang tidak sesuai, menu makanan yang pedas dan tidak bervariasi, serta santri tidak sarapan pagi [6]. Padahal menjaga pola makan yang baik dan sehat sangat penting selama pandemi COVID-19. Walaupun tidak ada makanan atau suplemen makanan yang dapat mencegah penularan virus COVID-19, namun mengubah pola makan dengan mengkonsumsi makan bergizi seimbang dan sehat sangat penting dalam meningkatkan sistem imunitas tubuh yang baik [7].

Salah satu cara mencapai kesehatan dan imunitas tinggi yaitu dengan mengkonsumsi makanan beragam dan gizi seimbang. Gizi seimbang merupakan susunan makanan sehari-hari yang mengandung zat gizi makro (karbohidrat, protein dan lemak) dan zat gizi mikro (vitamin dan mineral) [8]. Zat gizi ini berguna untuk memelihara dan meningkatkan kesehatan serta mendukung pertumbuhan dan perkembangan. Pada masa Covid-19 mengkonsumsi gizi seimbang penting untuk mencapai kesehatan optimum, dan meningkatkan kekebalan tubuh [8].

Penerapan gizi seimbang di lingkungan pesantren tentu menjadi suatu tantangan sendiri karena pola pengaturan makanan yang sentral yang harus mengakomodir banyaknya santri dengan kebutuhan yang berbeda. Untuk penyelenggaraan makanan dalam jumlah banyak seperti asrama perlu ada organisasi yang dikelola yang terdiri atas ketua, pengurus, dan anggota. Sebagai ketua atau pemimpin diharapkan mempunyai pengetahuan manajemen gizi penyelenggaraan makanan yang meliputi pengetahuan ilmu gizi dasar dan pengetahuan tentang pengadaaan bahan pangan, termasuk penyimpanan, pengolahan, penghidangan, evaluasi, dan pelaporan. Sebagai pengurus diharapkan terampil dalam mengelola keuangan, pembelanjaan bahan 


\section{Prosiding Seminar Nasional Kesehatan $\mathbf{2 0 2 1}$ Lembaga Penelitian dan Pengabdian Masyarakat Universitas Muhammadiyah Pekajangan Pekalongan}

pangan dan alat, penyimpanan bahan pangan, dan pengolahan bahan pangan. Sebagai anggota sebaiknya dipilih yang terampil dalam pelaksanaan pengolahan bahan pangan [9].

Untuk mencapai perubahan perilaku berupa penerapan gizi seimbang di pesantren perlu peningkatan pengetahuan dari pengurus pesantren yang menyediakan makanan. Perilaku kesehatan merupakan respons seseorang terhadap stimulus berkaitan dengan sakit dan penyakit, sistem pelayanan kesehatan, makanan minuman serta lingkungan. Perilaku kesehatan dipengaruhi oleh tiga faktor, yaitu faktor predisposisi (pengetahuan, sikap, pendidikan, pekerjaan dan ekonomi keluarga), faktor- faktor pendukung (ketersediaan alat kesehatan, sumber informasi), dan faktor pendorong (sikap dan perilaku petugas kesehatan [10]. Untuk itu, diperlukan buku panduan gizi seimbang di pesantren untuk meningkatkan pengetahuan bagi pengurus makanan dan pengurus kamar sehingga dapat memicu perubahan perilaku berupa penerapan gizi seimbang di pesantren.

Berdasarkan hal tersebut maka LPPM Akper Al Hikmah 2 Brebes merasa perlu melakukan pengabdian masyarakat dengan tujuan melakukan edukasi terkait gizi pada santri. Pengabdian ini bertujuan untuk memberikan informasi seputar nutrisi selama pandemi COVID-19 sehingga dapat mengubah perilaku masyarakat terutama santri serta mewadahi subjek untuk konfirmasi berbagai hoaks yang beredar seputar COVID19 maupun masalah nutrisi.

\section{Metode}

Kegiatan Pengabdian masyarakat ini dilakukan oleh LPPM Akper Al Hikmah 2 Brebes dengan memberikan edukasi melalui seminar dan pembagian buku pedoman gizi seimbang bagi santri di masa pandemi Covid-19. Tim pengabdian masyarakat sebelumnya melakukan survey terkait kondisi santri terutama yang berkaitan dengan gizi beserta masalah-masalah yang muncul di lingkungan pondok pesantren. Mitra pengabdian masyarakat adalah santri di Pondok Pesantren Zayyinul Huda yang terdiri dari pengurus kamar, santri bagian memasak dan perwakilan santri per kamar. Jumlah peserta yang hadir sebanyak 57 santriwan dan santriwati.

Adapun tahapan-tahapan proses pengabdian masyarakat yang dilakukan adalah sebagai berikut: 1). Survey awal yaitu analisis situasi dan kondisi pada mitra sebagai landasan pemilihan materi edukasi yang akan diberikan dengan cara diskusi langsung bersama pimpinan pondok pesantren dan pengurus santri Pondok Pesantren Zayyinul Huda; 2). Melakukan kontrak waktu kegiatan dengan pimpinan pondok pesantren dan pengurus terkait jenis kegiatan dan waktu kegiatan; 3). Implementasi kegiatan dan evaluasi kegiatan.

\section{Hasil dan Pembahasan}

Kegiatan pengabdian masyarakat merupakan tri dharma perguruan tinggi yang tetap harus dilakukan walaupun dalam keadaan pandemi Covid-19. Kegiatan Pengabdian masyarakat ini dilakukan pada tanggal 31 Mei 2021 di Pondok Pesantren Zayyinul Huda. Pandemi COVID-19 menyebabkan banyak perubahan dalam kehidupan sehari-hari. Gizi yang baik juga sangat penting sebelum, selama dan setelah infeksi. Infeksi virus menyebabkan tubuh menjadi demam sehingga membutuhkan tambahan 


\section{Prosiding Seminar Nasional Kesehatan Lembaga Penelitian dan Pengabdian Masyarakat Universitas Muhammadiyah Pekajangan Pekalongan}

energi dan zat gizi. Karena itu, menjaga pola makan yang sehat sangat penting selama masa pandemi Covid-19. Meskipun tidak ada makanan atau suplemen makanan yang dapat mencegah infeksi Covid-19, mempertahankan gizi seimbang yang sehat sangat penting dalam meningkatkan sistem kekebalan tubuh yang baik. Untuk menghadapi ini diperlukan panduan gizi seimbang pada masa pandemi Covid-19 [11]. Untuk menghadapi situasi ini, diperlukan adanya panduan gizi seimbang pada masa pandemi Covid-19. Oleh karena itu kegiatan pengabdian masyarakat diantaranya adalah memberikan Buku Panduan dan memberikan edukasi terkait Gizi Seimbang pada masa Pandemi Covid-19.

COVID-19 memberikan dampak yang luas termasuk terhadap pendidikan, sosial, dan ekonomi [2]. Masalah kesehatan yang ditimbulkan bukan hanya masalah infeksi namun juga menyentuh ranah nutrisi mulai dari kerentanan terjadinya malnutrisi, masalah keamanan pangan, ketahanan pangan, serta penyakit metabolik [3][4]. Hal ini perlu dipahamkan kepada masyarakat agar masyarakat juga waspada dengan masalah nutrisi yang dapat terjadi selama pandemi.

Konsumsi Gizi seimbang sangat penting bagi remaja pada masa Pandemi Covid19, selain untuk tumbuh dan berkembang juga untuk meningkatkan imunitas tubuh dan mencapai tingkat kesehatan yang prima. Hal ini dapat dicapai bila dapat mengaplikasikan Pesan Gizi Seimbang yang sudah dikeluarkan oleh Kementerian Kesehatan tahun 2014.

Remaja yang sedang bertumbuh dan berkembang memerlukan nutrisi yang seimbang, baik zat gizi makro dan mikro. Berdasarkan AKG 2013, kecukupan gizi pada remaja laki-laki antara 2400-2800 kalori, sedangkan perempuan berisar antara 20002200 kalori [12]. Jumlah tersebut dapat terpenuhi bila frekuensi makanan tiga kali sehari [13]. Sarapan dengan mengkonsumsi makanan bersumber karbohidrat, protein, mineral dan vitamin sangat berguna dalam berkonsentrasi, menjaga kesehatan dan untuk tumbuh serta berkembang [13]. Sarapan juga penting untuk menjaga stamina tubuh pada masa Covid-19. Sarapan pagi merupakan salah satu pesan gizi seimbang untuk menjamin terpenuhinya kebutuhan tubuh pada pagi hari, terutama karbohidrat, yang berfungsi menyeimbangkan kadar gula dalam darah sebagai sumber energi dan, kerja otak [13]. Berdasarkan hasil survey, banyak santri yang melewatkan sarapan dikarenakan banyak alasan diantaranya adalah lauk yang tidak cocok, belum nafsu makan dan terburu-buru.

Lauk hewani sebagai sumber protein mempunyai nilai biologi tinggi direkomendasikan untuk remaja laki-laki umur 15 -18 tahun $0.9 \mathrm{gram} / \mathrm{kg} \mathrm{BB}$, sedangkan perempuan $0.8 \mathrm{gram} / \mathrm{kg}$ berat badan [12]. Berdasarkan hasil survey, makanan yang dikonsumsi santri tidak lah selalu memenuhi kriteria seimbang. Hal ini berkaitan dengan kondisi ekonomi santri. Sistem catering makanan di Pondok Pesantren ini adalah santri membayar sebesar seribu rupiah per hari untuk lauk pauknya sedangkan nasi memasak sendiri. Uang yang terkumpul dibelanjakan untuk membeli bahan sayuran dan lauk pauk. Jika santri tidak berkenan maka dipersilahkan membeli lauk tambahan di luar. Jika asupan gizi yang masuk kurang mengandung protein pastinya berpengaruh terhadap sistem imun. Protein yang diperoleh dari lauk hewani sebagai zat pembangun, memelihara jaringan tubuh, dan pengatur proses 


\section{Prosiding Seminar Nasional Kesehatan 2021 Lembaga Penelitian dan Pengabdian Masyarakat Universitas Muhammadiyah Pekajangan Pekalongan}

metabolisma serta pertahanan tubuh untuk melawan mikroba dan zat toksik yang masuk kedalam tubuh [8]. Masa Covid-19 ini penting sekali mengkomsumsi lauk hewani, untuk pertahanan tubuh dari mikroorganisme.

Sayur dan buah mengandung vitamin dan mineral penting dalam memenuhi kebutuhan tubuh, mengatur proses metabolisme, mempertahankan fungsi jaringan dan menyokong pembentukan sel-sel baru tubuh. Pada remaja kebutuhan vitamin dan mineral meningkat, untuk pertumbuhan terutama rangka atau tulang. Selain itu pada masa Covid-19 vitamin dan mineral, terutama vitamin A, C, D, E, dan zat besi serta zink, berperan sebagai anti oksidan dan meningkatkan imunitas tubuh.4 Pesan Gizi Seimbang telah menganjurkan konsumsi sayur dan buah perlu memenuhi separuh dari piring makanku,begitu juga Gerakan Masyarakat Sehat (GERMAS) menyarankan konsumsi sayur dan buah setiap hari sebanyak 3 - 4 porsi/hari, buah 2 - 3 porsi/hari (Kemenkes RI, 2017). Hasil survey di santri didapatkan data bahwa santri makan makanan sayur terpenuhi, karena setiap hari menu makannya adalah sayur-sauran yang dibeli di pasar dan dimasak oleh pengurus untuk dimakan bersama-sama. Namun untuk konsumsi buahnya belum terpenuhi maksimal. Santri hanya memakan buah apa adanya yang tersedia. Biasanya kesediaan buah tergantung dari bekal yang dibawakan oleh keluarga saat santri mudik. Selain itu, sumber konsumsi buah didapatkan dari hasil kebun pondok yangmana tidak panen setiap hari. Penambahan konsumsi sayur dan buah ini sangat penting pada masa Covid-19, untuk meningkatkan imunitas tubuh dalam menghadapi virulensi Covid-19 yang sangat tinggi.

Capaian hasil evaluasi didapatkan adanya peningkatan pengetahuan siswa siswi tentang Gizi seimbang di masa pandemi Covid-19. Hasil evaluasi post test menunjukkan peningkatan nilai dibandingkan dengan pre test yaitu sebesar 57,5 jadi 75,7. Hasil yang diperoleh sesuai dengan penelitian Asfar dan Asnaniar (2018)[14] yang menyatakan bahwa ada peningkatan skor rata-rata pengetahuan remaja setelah pemberian penyuluhan kesehatan. Peningkatan pengetahuan remaja salah satunya didukung oleh penggunaan media leaflet. Isi leaflet sesuai dengan materi penyuluhan yang disampaikan dengan gambar dan warna serta menyajikan seluruh poin-poin materi pada leaflet di dalam kuesioner. Leaflet sangat efektif dalam meningkatkan efektifitas penyuluhan dengan metode ceramah, karena leaflet selain merangkum dari keseluruhan materi penyuluhan, juga menyajikan gambar menarik yang memudahkan seseorang memahami isi materi [15]. Kegiatan pada pengabdian masyarakat ini menggunakan leaflet yang telah disusun sesuai dengan materi penyuluhan yang dibutuhkan remaja.

\section{Kesimpulan}

Kegiatan pengabdian ini telah meningkatkan pengetahuan santri tentang gizi seimbang terutama pada masa pandemi Covid-19. Terdapat peningkatan pengetahuan santri tentang gizi seimbang dengan edukasi menggunakan media powerpoint, leaflet dan buku panduan yang disusun berdasarkan kemenkes 2020 tentang Panduan Gizi Seimbang Di Masa Pandemi Covid-19. Hal ini bagus untuk meningkatkan imunitas santri di masa pandemi untuk mencegah tertular Covid-19. 


\section{Prosiding Seminar Nasional Kesehatan 2021 \\ Lembaga Penelitian dan Pengabdian Masyarakat Universitas Muhammadiyah Pekajangan Pekalongan}

Dari kesimpulan tersebut maka direkomendasikan kepada pesantren untuk memfasilitasi santri agar peningkatan pengetahuan yang ada dapat memicu penerapan pola hidup sehat dan menerapkan gizi seimbang di pesantren.

\section{Ucapan Terima Kasih (jika ada)}

Ucapan terimakasih diberikan kepada Pimpinan Pondok Pesantren Zayyinul Huda beserta segenap pengurus pondok. Penulis juga mengucapkan terimakasih kepada para revieweryang telah memberikan masukan.

\section{Referensi}

[1] V. TP and M. CG, "The COVID-19 epidemic," Trop Med Int Heal., vol. 25, no. 3, pp. 278-280, 2020.

[2] E. Engkus, N. Suparman, F. Tri Sakti, and Saeful Anwar, H., "Covid-19: Kebijakan mitigasi penyebaran dan dampak sosial ekonomi di Indonesia.," LP2M, 2020.

[3] R. S. Prawiradilaga, "COVID-19 dan tatalaksana gizi," Pus. Pnb. Unisba LPPM UNISBA, 2020.

[4] B. Saragih and Saragih FM., "Hubungan Berbagai Faktor Dengan Kebiasaan Makan Pada Masa Pandemi Covid 19," p. https://www.researchgate.net/, 24Mar-2020.

[5] W. IMK, A. NNM, and M. GDT., "Pengetahuan, Sikap dan Aktivitas Remaja SMA dalam Kesehatan Reproduksi di Kecamatan Buleleng," Obesitas Sent Dan Kadar Koles Darah Total., vol. 10, no. 1, pp. 33-42, 2014.

[6] Yusnita, D. Widianti, and Citra Dewi, "Upaya penerapan gizi seimbang di Pesantren sebagai bagian dari pemberdayaan Poskestren," Pros. SNaPP 2015 Kesehat., pp. 37-44, 2015.

[7] D. M. Akbar and Z. Aidha, "PERILAKU PENERAPAN GIZI SEIMBANG MASYARAKAT KOTA BINJAI PADA MASA PANDEMI COVID-19 TAHUN 2020," J. Menara Med., vol. 3, no. 1, pp. 15-21, 2020.

[8] Mulyani EY, "Asupan Gizi dalam Upaya Meningkatkan Imunitas di Masa Pandemi Covid-19," 2020. [Online]. Available: https://lppm.esaunggul.ac.id/tag/asupangizi-dalam-upaya-meningkatkan-imunitas-di-masa-pandemi-covid-19/.

[9] D. RI, Pedoman Penyelenggaraan Makanan Rumah Sakit. Direktorat. Jenderal Bina Pelayanan Medik. Jakarta: Gramedia Pustaka Utama, 2007.

[10] S. Notoatmodjo, Promosi Kesehatan dan Ilmu Perilaku. Jakarta: Rineka Cipta, 2007.

[11] Kemenkes RI, "Panduan Gizi Seimbang COVID-19.pdf." 2020.

[12] Hardinsyah and I. Supariasa, IImu Gizi Teori dan Aplikasinya. Jakarta: EGC, 2017.

[13] Kemenkes RI, Pedoman Konversi Berat Matang-Mentah, Berat Dapat Dimakan (BDD) dan Resep Makanan Siap Saji dan Jajanan. Jakarta: Kementerian Kesehatan Republik Indonesia., 2014.

[14] A. Asnaniar, W., \& Asfar, "Analisis Status Gizi Lansia Berdasarkan Indeks Massa Tubuh (IMT) dan Mini Nutritional Assesment (MNA)," J. IIm. Kesehat. Diagnosis, 2018. 


\section{Prosiding Seminar Nasional Kesehatan Lembaga Penelitian dan Pengabdian Masyarakat Universitas Muhammadiyah Pekajangan Pekalongan}

[15] S. A and K. FJ., "Pengaruh penyuluhan dan pelatihan melalui media leaflet terhadap pengetahuan kader PHBS di Kecamatan Ratolindo kabupaten Tojo Unauna," Promot. J. Kesehat. Masyarakat., vol. 8, no. 2, pp. 159-164, 2018.

[1] V. TP and M. CG, "The COVID-19 epidemic," Trop Med Int Heal., vol. 25, no. 3, pp. 278-280, 2020.

[2] E. Engkus, N. Suparman, F. Tri Sakti, and Saeful Anwar, H., "Covid-19: Kebijakan mitigasi penyebaran dan dampak sosial ekonomi di Indonesia.," LP2M, 2020.

[3] R. S. Prawiradilaga, "COVID-19 dan tatalaksana gizi," Pus. Pnb. Unisba LPPM UNISBA, 2020.

[4] B. Saragih and Saragih FM., "Hubungan Berbagai Faktor Dengan Kebiasaan Makan Pada Masa Pandemi Covid 19," p. https://www.researchgate.net/, 24Mar-2020.

[5] W. IMK, A. NNM, and M. GDT., "Pengetahuan, Sikap dan Aktivitas Remaja SMA dalam Kesehatan Reproduksi di Kecamatan Buleleng," Obesitas Sent Dan Kadar Koles Darah Total., vol. 10, no. 1, pp. 33-42, 2014.

[6] Yusnita, D. Widianti, and Citra Dewi, "Upaya penerapan gizi seimbang di Pesantren sebagai bagian dari pemberdayaan Poskestren," Pros. SNaPP 2015 Kesehat., pp. 37-44, 2015.

[7] D. M. Akbar and Z. Aidha, "PERILAKU PENERAPAN GIZI SEIMBANG MASYARAKAT KOTA BINJAI PADA MASA PANDEMI COVID-19 TAHUN 2020," J. Menara Med., vol. 3, no. 1, pp. 15-21, 2020.

[8] Mulyani EY, "Asupan Gizi dalam Upaya Meningkatkan Imunitas di Masa Pandemi Covid-19," 2020. [Online]. Available: https://Ippm.esaunggul.ac.id/tag/asupangizi-dalam-upaya-meningkatkan-imunitas-di-masa-pandemi-covid-19/.

[9] D. RI, Pedoman Penyelenggaraan Makanan Rumah Sakit. Direktorat. Jenderal Bina Pelayanan Medik. Jakarta: Gramedia Pustaka Utama, 2007.

[10] S. Notoatmodjo, Promosi Kesehatan dan Ilmu Perilaku. Jakarta: Rineka Cipta, 2007.

[11] Kemenkes RI, "Panduan Gizi Seimbang COVID-19.pdf." 2020.

[12] Hardinsyah and I. Supariasa, IImu Gizi Teori dan Aplikasinya. Jakarta: EGC, 2017.

[13] Kemenkes RI, Pedoman Konversi Berat Matang-Mentah, Berat Dapat Dimakan (BDD) dan Resep Makanan Siap Saji dan Jajanan. Jakarta: Kementerian Kesehatan Republik Indonesia., 2014.

[14] A. Asnaniar, W., \& Asfar, "Analisis Status Gizi Lansia Berdasarkan Indeks Massa Tubuh (IMT) dan Mini Nutritional Assesment (MNA)," J. IIm. Kesehat. Diagnosis, 2018.

[15] S. A and K. FJ., "Pengaruh penyuluhan dan pelatihan melalui media leaflet terhadap pengetahuan kader PHBS di Kecamatan Ratolindo kabupaten Tojo Unauna," Promot. J. Kesehat. Masyarakat., vol. 8, no. 2, pp. 159-164, 2018. 